\title{
Protective effect of hyaluronate on oxidative DNA damage in WI-38 and A549 cells
}

\author{
HONG ZHAO $^{1}$, TOSHIKI TANAKA ${ }^{1,2}$, VADIM MITLITSKI $^{3}$, JULIE HEETER ${ }^{3}$, \\ ENDRE A. BALAZS ${ }^{3}$ and ZBIGNIEW DARZYNKIEWICZ ${ }^{1}$
}

\begin{abstract}
${ }^{1}$ Brander Cancer Research Institute and Department of Pathology, New York Medical College, Valhalla, NY 10595, USA;
${ }^{2}$ First Department of Surgery, Yamaguchi University School of Medicine, 1-1-1 Minami kogushi, Ube, Yamaguchi 755-8505, Japan; ${ }^{3}$ Matrix Biology Institute, Suite 205, 725 River Road, Edgewater, NJ 07020, USA
\end{abstract}

Received February 4, 2008; Accepted March 18, 2008

\begin{abstract}
Progressive DNA damage in live cells by oxidants is the key factor contributing to cell aging and preconditioning to neoplastic transformation. The strategies to slow aging or prevent cancer rely on protection of DNA from the damage. Since cells reside within intercellular matrix it is of interest to know whether matrix constituents possess properties of modulating oxidative DNA damage. We explored, therefore, the effect of hyaluronate (HA), the ubiquitous component of the matrix, on extent of DNA damage induced by exogenous and endogenously generated oxidants. WI-38 and A549 cells were exposed to $200 \mu \mathrm{M} \mathrm{H}_{2} \mathrm{O}_{2}$ in the absence or presence of HA and induction of histone $\mathrm{H} 2 \mathrm{AX}$ phosphorylation and activation of ATM, the reporters of DNA damage, was assessed by multiparameter cytometry. Also explored was effect of HA on constitutive $\mathrm{H} 2 \mathrm{AX}$ phosphorylation that reflects DNA damage caused by endogenous oxidants generated during aerobic metabolism. HA of average MW 5.4 million (high MW) and 2 million (medium MW) at $0.1 \%$ $(\mathrm{w} / \mathrm{v})$ in culture medium totally prevented the $\mathrm{H}_{2} \mathrm{O}_{2}$-induced $\mathrm{H} 2 \mathrm{AX}$ phosphorylation in both cell types whereas effect of 60,000 average MW (low MW) HA was somewhat less pronounced. Constitutive H2AX phosphorylation in WI-38 cells growing in the presence of $0.1 \% \mathrm{HA}$ of low MW and medium MW was reduced by about 35 and $30 \%$, respectively; no reduction was observed in A549 cells. The data indicate that HA protected DNA from damage caused by the exogenous oxidant $\mathrm{H}_{2} \mathrm{O}_{2}$. In WI-38 fibroblasts, the cells that express the HA-receptor CD44, HA also protected DNA from damage caused by endogenous oxidants. We postulate that expression of CD44 in some cell types such as stem cells may provide the means to internalize HA by endocytosis and one of the
\end{abstract}

Correspondence to: Dr Z. Darzynkiewicz, Department of Pathology, Brander Cancer Research Institute, New York Medical College, BSB 438, Valhalla, NY 10595, USA

E-mail: darzynk@nymc.edu

Key words: hyaluronic acid, H2AX phosphorylation, ATM activation, reactive oxygen intermediates, cell cycle, stem cells, endocytosis, Fenton's reaction, CD44 functions of the internalized HA may be protection of DNA from oxidants. The mechanism of protective effect of HA may either: i) involve entrapment of iron ions thereby inhibiting the Fenton's reaction that produces secondary oxidative species, and/or: ii) directly scavenging of primary and secondary ROIs, as an antioxidant, resulting in HA degradation. Since no significant degradation of HA upon its exposure in tissue culture medium to $\mathrm{H}_{2} \mathrm{O}_{2}$ was detected the scavenging may occur intracellularly.

\section{Introduction}

DNA in live cells is being constantly damaged by reactive oxygen species (ROS) either generated during aerobic respiration in mitochondria (1-6), or originating from exogenous sources such as environmental pollutants (7), macrophage oxidative burst (8-10), and other factors (11). The by-products of oxidative phosphorylation reactions can diffuse from mitochondria and reach the nuclear DNA inducing its damage $(12,13)$. Oxidation of all four constituent DNA bases with predominance of guanine [formation of 8-oxo-7,8-dihydro2'-deoxyguanosine (8-oxo-dG)], base ring fragmentation, sugar modification, covalent crosslinking of DNA and protein, and induction of DNA strand breaks, all may occur as a result of oxidative DNA damage $(14,15)$. Lipid peroxidation of cell membranes is still another injurious effect of endogenous and exogenous oxidants (16).

It has been estimated that during a single cell cycle of about 24-h duration approximately 5,000 DNA single-strand lesions (SSLs) per nucleus are generated by oxidants (6). Of them about $1 \%$ ( 50 'endogenous DSBs') are converted, predominantly during DNA replication, to DNA double-strand breaks (DSBs). Recombinatorial repair and non-homologous DNA-end joining (NHEJ) are the two major pathways of DSB repair. Recombinatorial repair takes place in cells that have already replicated some portion of their DNA that can then serve as a template, i.e. in late $S$ and $G_{2}$ phase cells. DNA repair in $G_{1}$ and early $S$ phase cells that lack a template, however, relies on the NHEJ pathway, which is error-prone and may lead to deletion of some base pairs $(16,17)$. Progressive alteration in molecular structure of DNA occurring by this mechanism in live cells is considered to be the main cause of aging and 
senescence as well as predisposition to cancer (4,18-22). Therefore, the strategies designed to slow aging or prevent cancer rely on protection of DNA from oxidative damage, primarily by the use of anti-oxidants.

Since cells within tissues are embedded in the intercellular matrix it is of interest to know whether components of intercellular matrix possess properties of modulating extent of ROS and can affect oxidative DNA damage. Indeed, there is evidence in the literature that some glycosaminoglycans such as chondroitin-4-sulfate and hyaluronan (hyaluronic acid, HA) inhibit lipid peroxidation caused by oxidative stress and thereby decrease inflammatory reactions mediated by oxidants (23-26). The anti-inflammatory effects of various forms of HA seen after administration into arthritic joints was also observed and considered to be due to restoration of elastoviscosity of the synovial fluid of the inflamed joints (27). However, the protective effect of this biopolymer through neutralization of reactive oxidants generated during inflammation-driven oxidative burst in leukocytes and macrophages may also play a role (8-10).

In the early $1940 \mathrm{~s}$, it was discovered that ascorbic acid or $\mathrm{H}_{2} \mathrm{O}_{2}$ causes degradation of HA. It was also observed that $\mathrm{Fe}^{2+}$ and $\mathrm{Cu}^{2+}$ ions and molecular oxygen catalyzed this 'oxidative degradation' producing oligosaccharides $(28,29)$. Later it was suggested that oxygen-derived free radicals initiated the reaction $(30,31)$. The reaction can be inhibited by various scavengers of oxygen-derived free radicals such as superoxide dismutase, catalase, and mannitol, histidine or copper-penicillamine complex (32). The stimulatory effect of low concentration of $\mathrm{H}_{2} \mathrm{O}_{2}(1-5 \mu \mathrm{M})$ on HA synthesis by cultured synovial cells of osteoarthritic but not of rheumatoid arthritic patients (33) was reported.

Data in the literature indicated that the concentration of $\mathrm{H}_{2} \mathrm{O}_{2}$ used both in vitro and in cell culture experiments is an important factor on the HA degradation process. Therefore, we studied the effect of $200 \mu \mathrm{M}$ and $200 \mathrm{mM} \mathrm{H}_{2} \mathrm{O}_{2}$ on the three different average MW hyaluronan preparations dissolved in the various culture media used. We found that the $200 \mathrm{mM}$ $\mathrm{H}_{2} \mathrm{O}_{2}$ caused considerable degradation especially of the high and medium average MW HA preparations during 4-h incubation at $37^{\circ} \mathrm{C}$ (data not shown). Our goal was to use a $\mathrm{H}_{2} \mathrm{O}_{2}$ concentration that does not cause significant $\mathrm{HA}$ degradation during the 4-h period and therefore the cells were exposed during the entire culturing time to an unchanged HA molecular environment, we selected the lower concentration of $\mathrm{H}_{2} \mathrm{O}_{2}(200 \mu \mathrm{M})$ for our study. Recently, the effect of antiinflammatory drugs (naproxen, acetylsalicylic acid) was tested in vitro on the degradation of $\mathrm{HA}$ in the ascorbate, $\mathrm{H}_{2} \mathrm{O}_{2}$ and $\mathrm{Cu}^{2+}$-induced oxidative systems. The presence of these drugs retarded or inhibited the degradation of $\mathrm{HA}$ in a dosedependant manner. In these experiments 50-100 $\mu \mathrm{M} \mathrm{H}_{2} \mathrm{O}_{2}$ was used (34).

Activation of ataxia telangiectasia mutated (ATM) protein kinase through its phosphorylation on Ser-1981 (ATM$\mathrm{S} 1981^{\mathrm{P}}$ ), and phosphorylation of one of the variants of histone H2A, histone H2AX on Ser-139 are early reporters of a cell's response to DNA damage, particularly the damage that involves formation of DNA double-strand breaks (DSBs) (35-40). Phosphorylated H2AX has been named $\gamma \mathrm{H} 2 \mathrm{AX}$
$(35,36)$. These modifications of ATM and H2AX trigger signal transduction pathways that recruit DNA repair machinery to the DSB site and activate cell cycle checkpoints halting progression through the cycle. We have recently reported that immunocytochemical detection of ATM activation and H2AX phosphorylation when assessed by flow- or laserscanning cytometry provides a very sensitive marker of DNA damage, including the damage-induced endogenous oxidants $(8,41-44)$. In fact, the cytometric detection of DNA damage through the analysis of $\gamma \mathrm{H} 2 \mathrm{AX}$ expression has been reported to be by two orders of magnitude more sensitive than the alternative approach the comet methodology that is based on single cell DNA gel electrophoresis (45). In the present study, therefore, we have applied the $\mathrm{H} 2 \mathrm{AX}$ phosphorylation assay to explore whether HA may exert protective effect on oxidative DNA damage induced either by exogenous or endogenous oxidants. Towards this end we tested the effect of HA preparations of three different average MW and polydipersity on the level of: a) $\mathrm{H} 2 \mathrm{AX}$ phosphorylation induced by exogenously applied oxidative agent $\mathrm{H}_{2} \mathrm{O}_{2}$, and b) constitutive $\mathrm{H} 2 \mathrm{AX}$ phosphorylation (CHP) which reports DNA damage caused by endogenous oxidants generated during metabolic mitochondrial activity $(41-43,46)$.

\section{Materials and methods}

Cells, cell treatment. A549 and WI-38 cells, obtained from American Type Culture Collection (ATCC, Manassas, VA), were grown in Dulbecco's minimum essential medium (DMEM) supplemented with 10\% fetal bovine serum, $100 \mathrm{U} /$ $\mathrm{ml}$ penicillin, $100 \mu \mathrm{g} / \mathrm{ml}$ streptomycin and $2 \mathrm{mM}$ L-glutamine (Gibco/BRL) in $25 \mathrm{ml} \mathrm{Falcon} \mathrm{flasks} \mathrm{(Becton-Dickinson}$ Co., Franklin Lakes, NJ) at $37.5^{\circ} \mathrm{C}$ in atmosphere of $95 \%$ air and $5 \% \mathrm{CO}_{2}$. The cells were maintained in exponential and asynchronous phase of growth by repeated trypsinization and reseeding before reaching subconfluency. The cells were then trypsinized and seeded at low density (about $5 \times 10^{4}$ cells per chamber) in 2-chambered Falcon Culture Slides (Becton-Dickinson Labware). Twenty-four hours after seeding cells on slides the sterile solution of HA $(0.5 \% \mathrm{w} / \mathrm{v}$ in PBS; Matrix Biology Institute, Edgewater, NJ) was added to cultures to obtain the final $0.1 \%$ w/v HA concentration; the respective control cultures were supplemented with the equivalent volumes of PBS. HA of thee different average MW: 5.4 million (defined thereafter as high MW), 2 million (defined as medium MW) and 60,000 (low MW) were used throughout the experiments, as listed in Results and in figure legends. The cells were treated with $200 \mu \mathrm{M} \mathrm{H}_{2} \mathrm{O}_{2}$ (Sigma Chemical Co., St. Louis, MO) for various periods of time as shown in figure legends. In some experiments the cells were exposed to $\mathrm{HA}$ for $23 \mathrm{~h}$ then rinsed and treated with $\mathrm{H}_{2} \mathrm{O}_{2}$ in the medium containing the same concentration of HA as used in the prior 23-h incubation.

Detection of ATM activation and H2AX phosphorylation. Following incubations with $\mathrm{HA}$ and/or $\mathrm{H}_{2} \mathrm{O}_{2}$ the cells were rinsed with $\mathrm{PBS}$ and then fixed by transferring the slides into Coplin jars containing 1\% methanol-free formaldehyde (Polysciences, Inc., Warrington, PA) in PBS for 15 min on ice followed by suspension in $70 \%$ ethanol where they were 

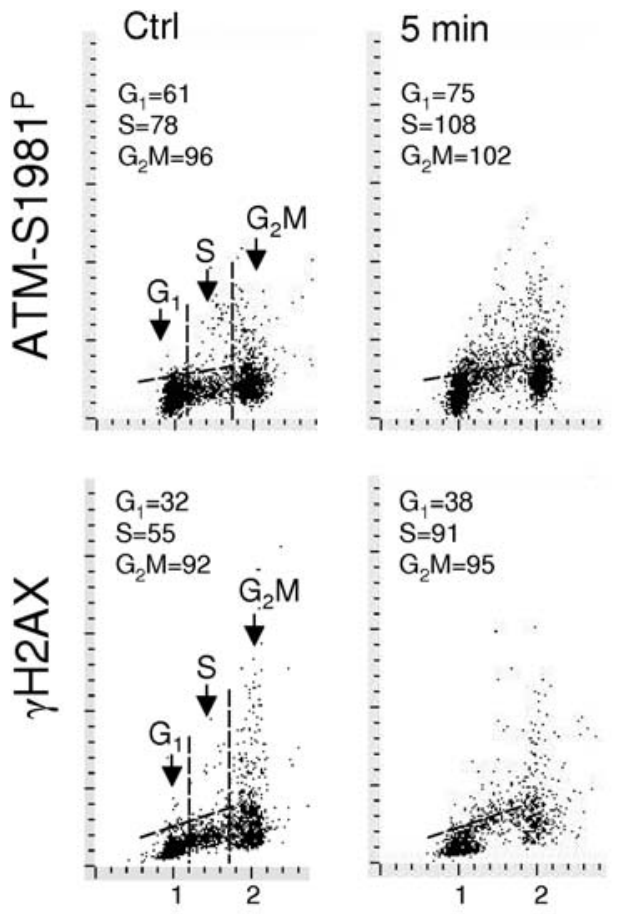
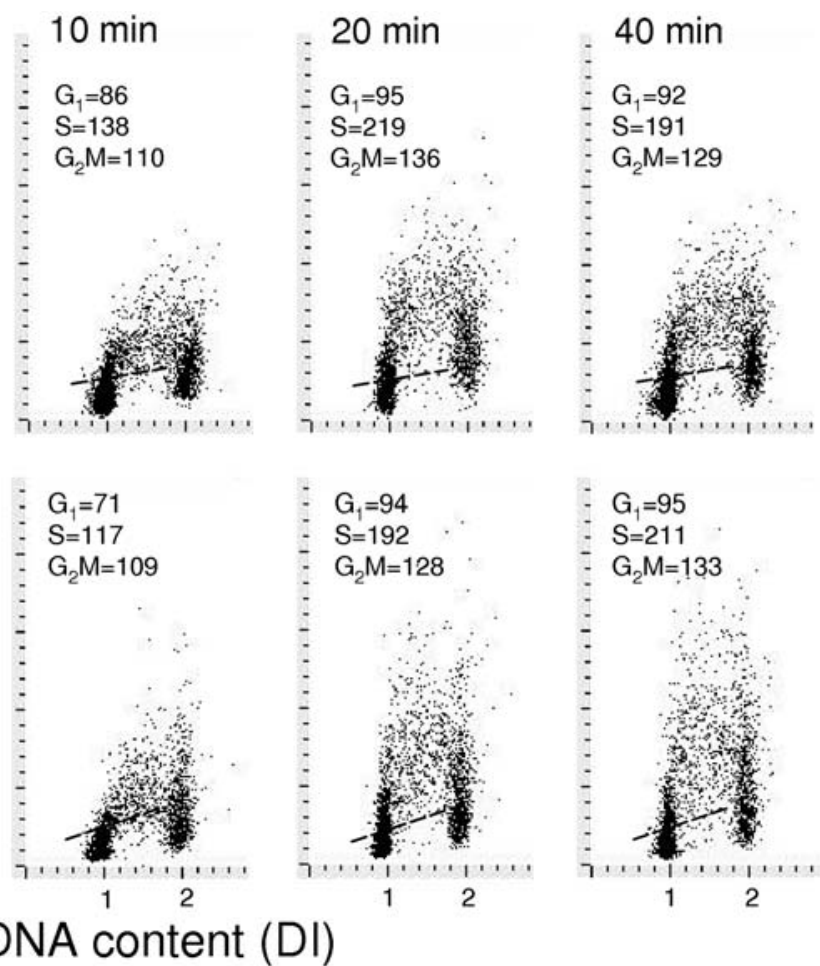

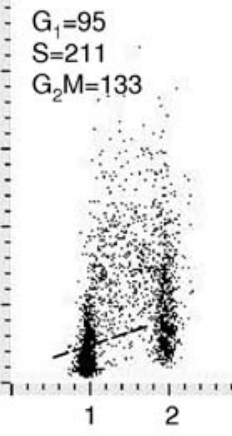

Figure 1. Induction of ATM activation and $\mathrm{H} 2 \mathrm{AX}$ phosphorylation in A549 cells exposed to $\mathrm{H}_{2} \mathrm{O}_{2}$. A549 cells were untreated $(\mathrm{Ctrl})$ or treated with $200 \mu \mathrm{M} \mathrm{H}_{2} \mathrm{O}_{2}$ for 5-40 min and expression of ATM-S1981 ${ }^{\mathrm{P}}$ and $\gamma \mathrm{H} 2 \mathrm{AX}$, each detected immunocytochemically, was measured by laser scanning cytometry, concurrently with cellular DNA content. The latter was used to identify cells in $\mathrm{G}_{1}, \mathrm{~S}$ and $\mathrm{G}_{2} \mathrm{M}$ phases of the cycle as shown in the left panels of these bivariate distributions (scatterplots). The dashed skewed lines show the upper threshold level of ATM-S1981 ${ }^{\mathrm{P}}$ and $\gamma \mathrm{H} 2 \mathrm{AX}$ expression for $97 \%$ of interphase cells in the untreated (Ctrl) cultures. By gating analysis based on differences in DNA content the mean values of $\gamma \mathrm{H} 2 \mathrm{AX}$ or ATM-S1981 ${ }^{\mathrm{P}}$ IF were calculated for cell populations in $\mathrm{S}$ phase (x) and are shown in each panel.

stored at $-20^{\circ} \mathrm{C}$ for $2-24 \mathrm{~h}$. The fixed cells were then washed twice in PBS and treated on slides with $0.1 \%$ Triton X-100 (Sigma) in a $1 \%(\mathrm{w} / \mathrm{v})$ solution of bovine serum albumin (BSA; Sigma) in PBS for 30 min to suppress non-specific antibody $(\mathrm{Ab})$ binding. The cells were then incubated in $100 \mu 1$ volume of 1\% BSA containing 1:200 dilution of phospho-specific (Ser-139) histone H2AX $(\gamma \mathrm{H} 2 \mathrm{AX})$ mouse monoclonal antibody (mAb) (Millipore/Upstate, Temecula, CA) or a 1:100 dilution of phospho-specific ATM (Ser-1981) $\mathrm{mAb}$ (Millipore/Upstate). After overnight incubation at $4^{\circ} \mathrm{C}$, the slides were washed twice with PBS and then incubated in $100 \mu 1$ of 1:100 dilution of Alexa Fluor 488 goat anti-mouse IgG $(\mathrm{H}+\mathrm{L})$ (Invitrogen/Molecular Probes, Eugene, OR) for $45 \mathrm{~min}$ at room temperature in the dark. The cells were then counterstained with either $2.8 \mu \mathrm{g} / \mathrm{ml} \mathrm{4,6-diamidino-2-}$ phenylindole (DAPI; Sigma) in PBS for $15 \mathrm{~min}$, or $5 \mu \mathrm{g} / \mathrm{ml}$ PI (Invitrogen/Molecular Probes) in the presence of $100 \mu \mathrm{g} / \mathrm{ml}$ of RNase A (Sigma). Each experiment was performed with an IgG control in which cells were labeled only with secondary antibody, Alexa Fluor 488 goat anti-mouse IgG $(\mathrm{H}+\mathrm{L})$ or Alexa Fluor 488 goat anti-rabbit IgG $(\mathrm{H}+\mathrm{L})$ without primary antibody incubation to estimate the extent of non-specific binding of the secondary antibody to the cells.

Measurement of cell fluorescence by Laser Scanning Cytometry. Cellular green fluorescence representing expression of $\gamma \mathrm{H} 2 \mathrm{AX}$, or of activated (Ser-1981 phosphorylated) ATM and blue emission of DAPI was measured using a Laser Scanning Cytometer (LSC; iCys; CompuCyte, Cambridge, MA), utilizing standard filter settings; fluorescence was excited with 488-nm argon ion and violet diode lasers, respectively (47). The intensities of maximal pixel and integrated fluorescence were measured and recorded for each cell. At least 3,000 cells were measured per sample. To express the treatment-induced change in mean values of the measured cells, the means values of the untreated as well as the treated cells were compensated for the level of non-specific fluorescence measured as described above. Each experiment was run in duplicate or triplicate and the experiments were repeated. Other details are given in figure legends.

Determination of average $M W$ and polydispersity of $H A$ samples. Average MW and the polydispersity of the HA molecules were determined by agarose gel electrophoresis $(34,48,49)$. The test samples contained $\mathrm{H}_{2} \mathrm{O}_{2}$ in two different concentrations $(200 \mathrm{mM}$ or $200 \mu \mathrm{M})$ in $0.1 \%(\mathrm{w} / \mathrm{v}) \mathrm{HA}$ solution in the same culture media (including antibiotics and fetal bovine serum) as used for culturing the studied cells. The freshly prepared samples were placed either immediately (time 0 ) or were incubated for 2 or $4 \mathrm{~h}$ at $37^{\circ} \mathrm{C}$ before being placed into the wells of the agarose gel. Depending on the average MW of HA either 0.5 or $1 \%$ agarose gel was used $(34,48,49)$. Monodisperse internal standards (Hyalose, L.L.C., Oklahoma City, $\mathrm{OH}$ ) were applied for each run.

\section{Results}

Exposure of A549 cells to $200 \mu \mathrm{M} \mathrm{H}_{2} \mathrm{O}_{2}$ resulted in rapid activation of ATM and induction of $\mathrm{H} 2 \mathrm{AX}$ phosphorylation (Fig. 1). Expression of ATM-S1981 ${ }^{\mathrm{P}}$ was already apparent 

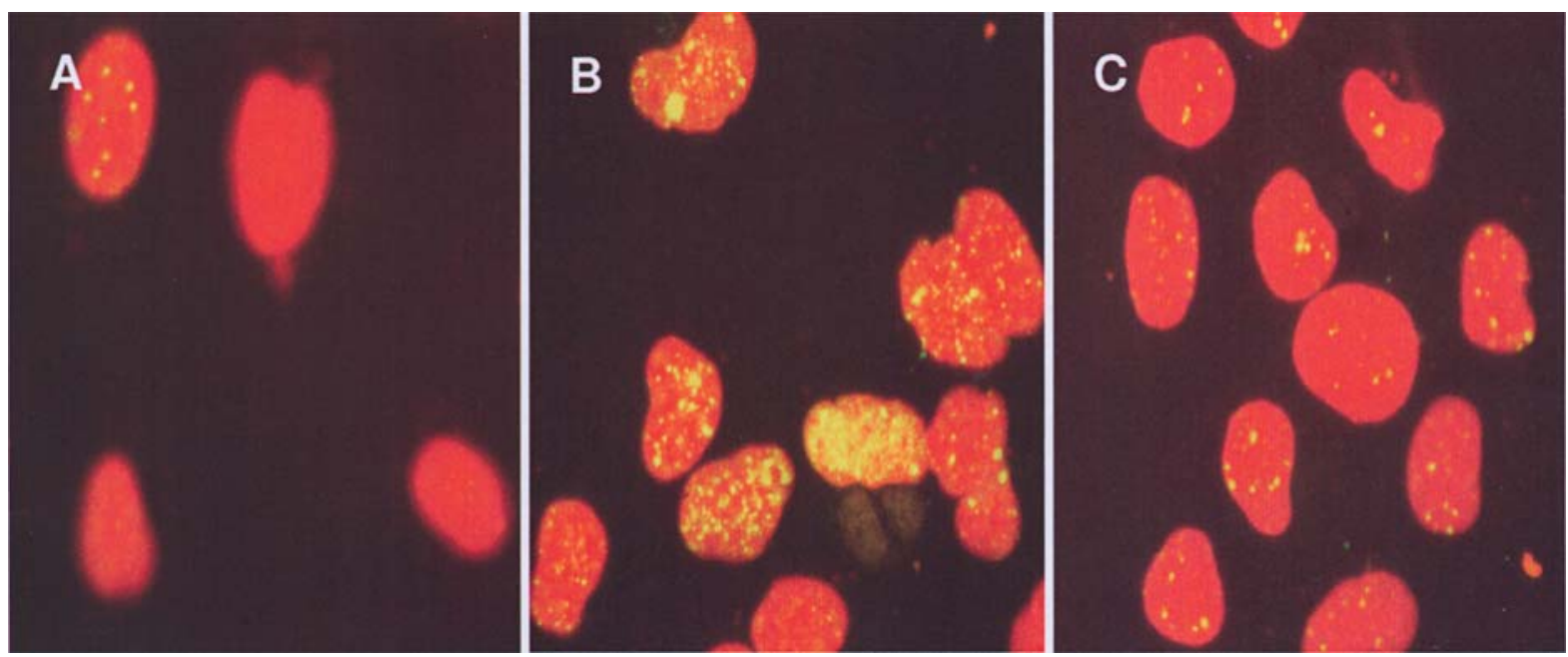

Figure 2. Effect of treatment of A549 cells with $\mathrm{H}_{2} \mathrm{O}_{2}$ in the absence and presence of high MW HA on induction of $\gamma \mathrm{H} 2 \mathrm{AX}$. Photomicrographs of A549 cells, untreated (A), treated with $200 \mu \mathrm{M} \mathrm{H}_{2} \mathrm{O}_{2}$ for 20 min in the absence of $\mathrm{HA}$ (B), and treated with $200 \mu \mathrm{M} \mathrm{H}_{2} \mathrm{O}_{2}$ for 20 min in the presence of $0.1 \%$ (w/v) of $\mathrm{HA}$ of high MW (C); HA was administered into the culture $1 \mathrm{~h}$ prior to $\mathrm{H}_{2} \mathrm{O}_{2}$. Expression of $\gamma \mathrm{H} 2 \mathrm{AX}$ is shown using Alexa 488 Fluor-tagged secondary Ab, DNA is counterstained with PI.
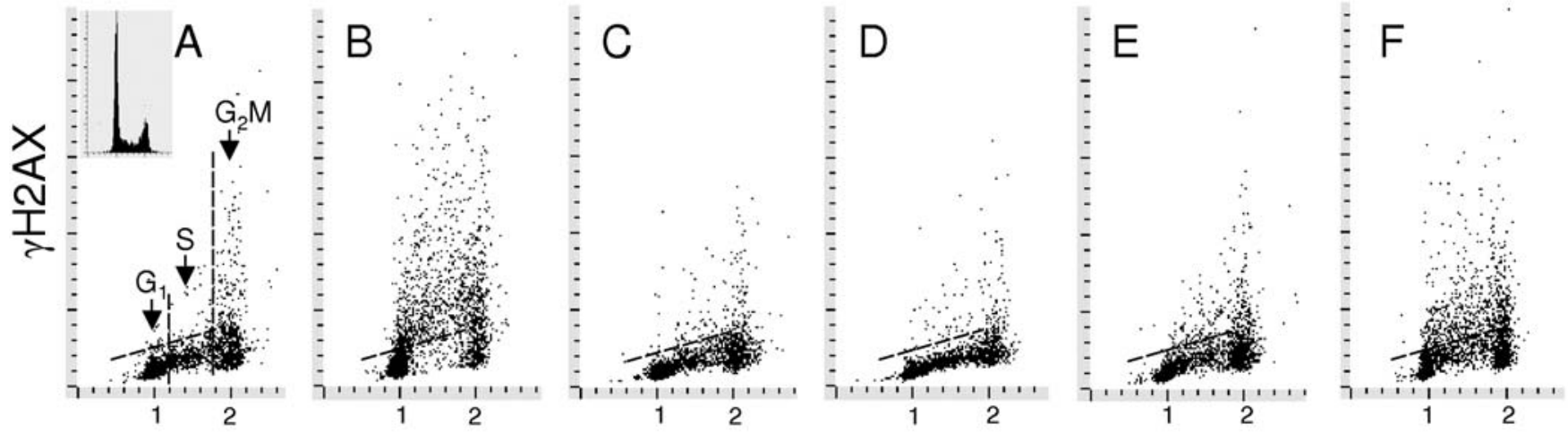

DNA content (DI)

Figure 3. Effect of $\mathrm{HA}$ on the $\mathrm{H}_{2} \mathrm{O}_{2}$-induced $\mathrm{H} 2 \mathrm{AX}$ phosphorylation in A549 cells. The bivariate DNA content vs. $\gamma \mathrm{H} 2 \mathrm{AX}$ distributions illustrate expression of $\gamma \mathrm{H} 2 \mathrm{AX}$ with respect to the cell cycle phase of the untreated cells (A), cells treated with $\mathrm{H}_{2} \mathrm{O}_{2}$ in the absence of $\mathrm{HA}$ (B) or treated with $\mathrm{H}_{2} \mathrm{O}_{2}$ in the presence of $0.1 \%$ HA of high MW (different batches, C and D), medium MW (E) and low MW (F), as described in Materials and methods. The dashed skewed lines show the upper threshold level of $\gamma \mathrm{H} 2 \mathrm{AX}$ expression for $97 \%$ of interphase cells in the untreated (Ctrl) culture (A). Based on differences in cellular DNA content it was possible to discriminate cells in $\mathrm{G}_{1}, \mathrm{~S}$ and $\mathrm{G}_{2} \mathrm{M}$ phases of the cell cycle as shown in A. The inset in A shows cellular DNA content histogram of the studied cultures; cell treatment with HA for $24 \mathrm{~h}$ had no detectable effect on DNA histogram (cell cycle distribution), regardless of MW of HA.

after 5 min of treatment and the level of $\gamma \mathrm{H} 2 \mathrm{AX}$ expression was elevated as well. Prolongation of the treatment up to 20-40 min led to further rise in the level of expression of both ATM-S1981 ${ }^{\mathrm{P}}$ and $\gamma \mathrm{H} 2 \mathrm{AX}$. Because cellular DNA content, the marker that identifies the cell cycle position, was measured concurrently with expression of ATM-S1981 ${ }^{\mathrm{P}}$ and $\gamma \mathrm{H} 2 \mathrm{AX}$, it was possible on the bivariate ATM-S1981 ${ }^{\mathrm{P}}$ or $\gamma \mathrm{H} 2 \mathrm{AX}$ versus DNA content distributions to correlate activation of ATM and phosphorylation with cell cycle phase (Fig. 1, left panels). The data distinctly show that the $\mathrm{H}_{2} \mathrm{O}_{2}$-induced increase in expression of ATM-S1981 ${ }^{\mathrm{P}}$ or $\gamma \mathrm{H} 2 \mathrm{AX}$ was maximal for the $\mathrm{S}$ phase cells. This is evident by the fact that following $\mathrm{H}_{2} \mathrm{O}_{2}$ treatment the mean values of ATM-S1981 ${ }^{\mathrm{P}}$ or $\gamma \mathrm{H} 2 \mathrm{AX}$ IF were more elevated in S-phase than in $G_{1}$ or $G_{2} M$ cells. Also, the proportion of cells with
ATM-S1981 ${ }^{\mathrm{P}}$ or $\gamma \mathrm{H} 2 \mathrm{AX}$ expression above the maximal level representing untreated $(\mathrm{Ctrl})$ cells (threshold defined by the dashed lines) was the highest for cells in S-phase. Similar set of data was obtained for WI-38 cells treated with $\mathrm{H}_{2} \mathrm{O}_{2}$ (not shown).

The induction of $\gamma \mathrm{H} 2 \mathrm{AX}$ in cells exposed to $\mathrm{H}_{2} \mathrm{O}_{2}$ manifested in form of IF foci (Fig. 2). The microphotographs shown in this figure demonstrate formation of a large number of $\gamma \mathrm{H} 2 \mathrm{AX}$ IF foci in the cells that were exposed to $\mathrm{H}_{2} \mathrm{O}_{2}$ in the absence of HA (Fig. 2B). However, there was almost total suppression of $\gamma \mathrm{H} 2 \mathrm{AX}$ IF foci formation in the cells that were exposed to $\mathrm{H}_{2} \mathrm{O}_{2}$ in the presence of high MW HA.

Figs. 3 and 4 illustrate effect of $\mathrm{HA}$ on the $\mathrm{H}_{2} \mathrm{O}_{2}$-induced phosphorylation of histone $\mathrm{H} 2 \mathrm{AX}$ in $\mathrm{A} 549$ cells. It is quite evident from the raw data presented as cellular DNA content 


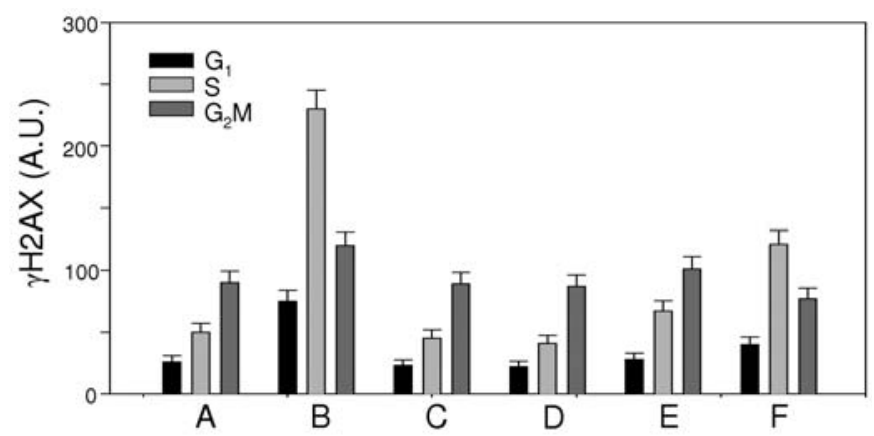

Figure 4. Mean values of $\gamma \mathrm{H} 2 \mathrm{AX}$ expression in A549 cells [in arbitrary units (AU); fluorescence channels] untreated or treated with $\mathrm{H}_{2} \mathrm{O}_{2}$ in the absence and presence of HA of different average MW in relation to the cell cycle phase. The data represent quantitative analysis of the experiment shown in Fig. 3 as the raw data represented by bivariate DNA content vs. $\gamma \mathrm{H} 2 \mathrm{AX}$ expression distributions. Based on differences in DNA content populations of cells in $\mathrm{G}_{1}, \mathrm{~S}$ and $\mathrm{G}_{2} \mathrm{M}$ phases were gated, their mean value of $\gamma \mathrm{H} 2 \mathrm{AX}$ expression was calculated and is presented $( \pm \mathrm{SE})$ as bar graphs.

versus $\gamma \mathrm{H} 2 \mathrm{AX}$ bivariate distributions (Fig. 3) that expression of $\gamma \mathrm{H} 2 \mathrm{AX}$ in $\mathrm{H}_{2} \mathrm{O}_{2}$-treated cells was markedly reduced in the cells that were growing in the presence of HA. The most pronounced were changes in $\gamma \mathrm{H} 2 \mathrm{AX}$ expression in S-phase cells. Maximal reduction was seen in cells treated with HA of high MW (Figs. 2C and 3C and D). Distinctly lower reduction was observed in the culture containing HA of low MW (Fig. 3F). The mean values of $\gamma \mathrm{H} 2 \mathrm{AX}$ expression calculated for cells in particular phases of cell cycle are presented in Fig. 4. The nearly 5-fold rise in $\gamma \mathrm{H} 2 \mathrm{AX}$ expression was apparent for the $\mathrm{S}$-phase cells exposed to $\mathrm{H}_{2} \mathrm{O}_{2}$ in the absence of HA (Fig. 4B). This increase was totally abolished when the cells were treated with $\mathrm{H}_{2} \mathrm{O}_{2}$ in the presence of high MW HA (Fig. 4C and D) and was significantly reduced in the presence of medium (Fig. 4E) and low MW HA (Fig. 4F).

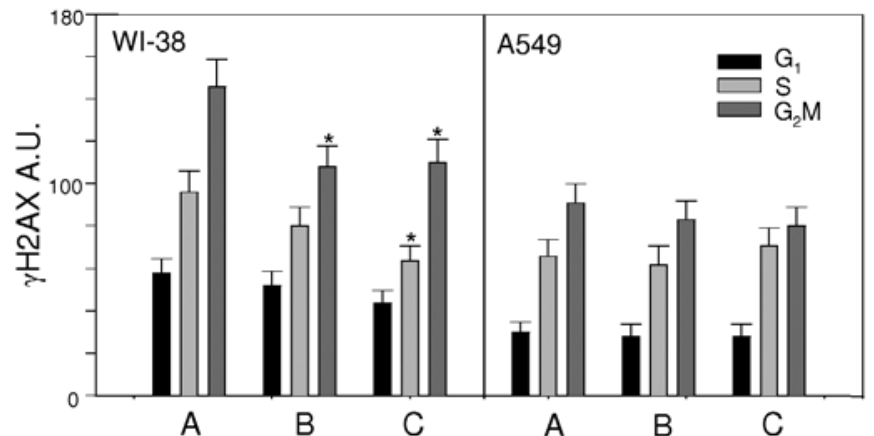

Figure 6. Mean values of $\gamma \mathrm{H} 2 \mathrm{AX}$ expression in WI-38 and A549 cells [in arbitrary units (AU); fluorescence channels] untreated (A) or treated with medium (B) or low (C) MW HA for $24 \mathrm{~h}$, in relation to the cell cycle phase. The data represent quantitative analysis of the experiment shown in Fig. 5. Populations of cells in $G_{1}, S$ and $G_{2} M$ phases were gated, their mean value of $\gamma \mathrm{H} 2 \mathrm{AX}$ expression was calculated and is presented ( $\pm \mathrm{SE}$ ) as bar graphs.

Marked proportion of constitutive histone H2AX phosphorylation seen in normal or tumor cells not treated by any exogenous genotoxic agent was shown to reflect oxidative DNA damage caused by ROS generated in mitochondria as by-products of aerobic metabolism $(41-44,46)$. We have tested whether HA may affect the level of constitutive H2AX phosphorylation by growing WI-38 and A549 cells in its presence and comparing expression of $\gamma \mathrm{H} 2 \mathrm{AX}$ in so treated cells with that of the untreated control cells (Figs. 5 and 6). It is evident from the raw data shown in Fig. 5 that expression of $\gamma \mathrm{H} 2 \mathrm{AX}$ was diminished in WI-38 cells grown in the presence of HA for $24 \mathrm{~h}$. The decrease was observed in cells treated with both medium and low MW HA, but the extent of decrease was somewhat more pronounced in the case of HA of the low MW. When expressed as mean values of $\gamma \mathrm{H} 2 \mathrm{AX}$ for particular phase of the cell cycle the decrease was statistically significant $(\mathrm{p}<0.05)$ for $\mathrm{G}_{2} \mathrm{M}$-phase cells in the cultures treated with HA of both medium and low MW and

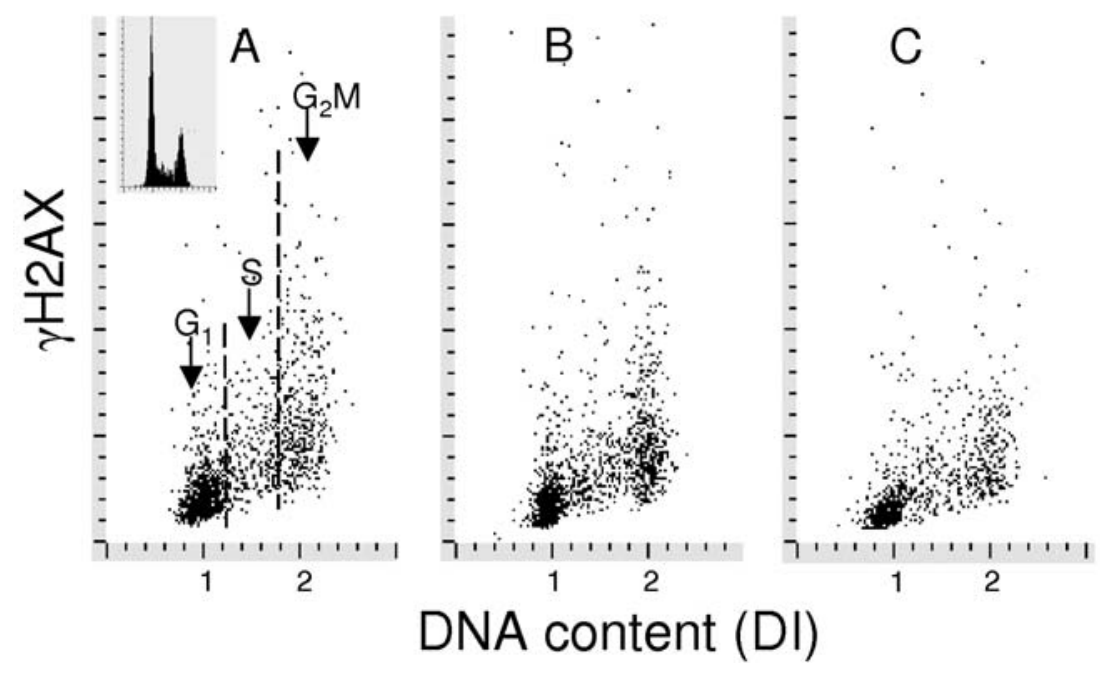

Figure 5. Effect of HA on the level of constitutive expression of $\gamma \mathrm{H} 2 \mathrm{AX}$ in WI-38 cells. Medium (B) and low (C) MW HA was present at $0.1 \%$ (w/v) concentration for $24 \mathrm{~h}$ in cultures of exponentially growing WI-38 cells; control (A) cells were left untreated. The cells were then harvested and expression of $\gamma \mathrm{H} 2 \mathrm{AX}$ as well as DNA content was measured by laser scanning cytometry. The inset in A shows DNA content histogram of the studied cultures; cell treatment with HA for $24 \mathrm{~h}$ had no detectable effect on DNA histogram regardless of its MW. Note a decrease in overall $\gamma \mathrm{H} 2 \mathrm{AX}$ level of the HA treated cells, more pronounced in cells treated with low MW HA. 


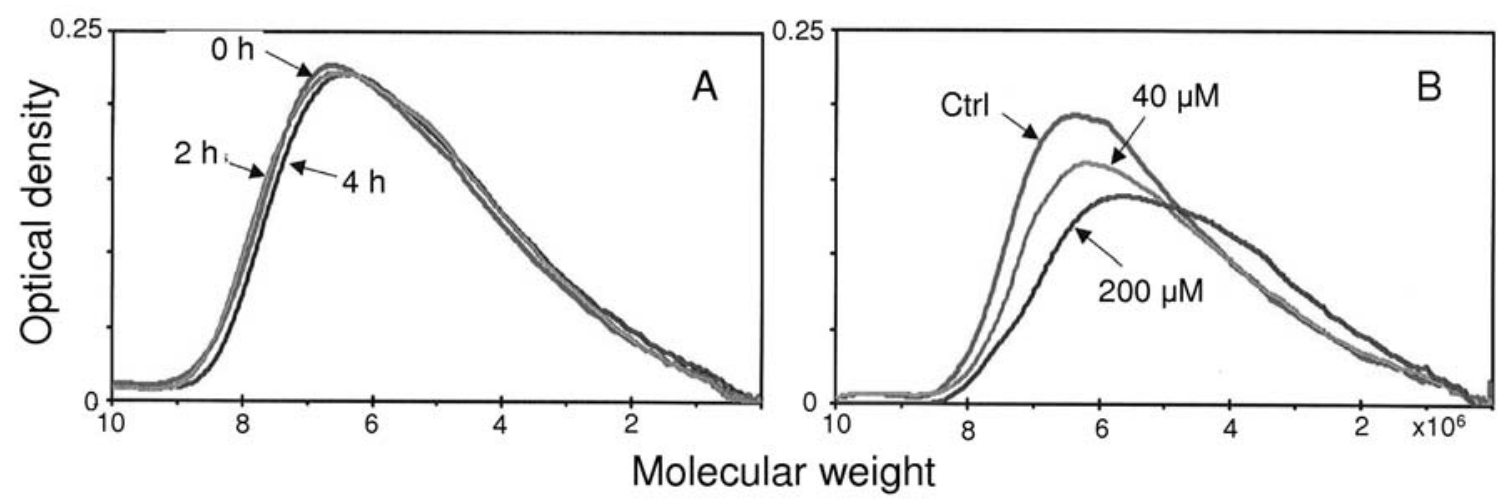

Figure 7. Different effects of $200 \mu \mathrm{M} \mathrm{H}_{2} \mathrm{O}_{2}$ on degradation of $\mathrm{HA}$ in the absence and presence of FeSO . A, $\mathrm{HA}$ of average MW 5.4 million was dissolved in culture medium (RPMI-1640 with penicillin, streptomycin and FBS) at $0.1 \%$ (w/v) concentration containing $\mathrm{H}_{2} \mathrm{O}_{2}$ and was incubated for 0,2 and 4 h at $37^{\circ} \mathrm{C}$. Note lack of the effect. B, The effect of 40 and $200 \mu \mathrm{M} \mathrm{FeSO}_{4}$ on the same HA preparation dissolved in the same culture media as in A. The average MW after 2 and $4 \mathrm{~h}$ of incubation at $37^{\circ} \mathrm{C}$ decreased by 5 and $14 \%$ respectively. The effect was most noticeable in the presence of $200 \mu \mathrm{M}$ of FeSO .

for S-phase cells in the cultures treated with low MW HA (Fig. 6). However, no such reduction was observed in the case of A549 (Fig. 6).

We also assessed as to whether HA was degraded when exposed to high $(200 \mathrm{mM})$ or low $(200 \mu \mathrm{M}) \mathrm{H}_{2} \mathrm{O}_{2}$ concentration. At $2 \mathrm{mM} \mathrm{H}_{2} \mathrm{O}_{2}$ concentration, the effect was significant, as after 4-h exposure the average MW of the high MW HA decreased $19 \%$ and that of the medium MW HA decreased $23 \%$. However, the low MW HA did not show any change (data not shown). On the other hand, we could not observe any effect of the low concentration $\mathrm{H}_{2} \mathrm{O}_{2}(200 \mu \mathrm{M})$ on HA degradation regardless of the MW (Fig. 7A). However, when $\mathrm{FeSO}_{4}$ was added to the reaction mixture, as expected, a small but significant degradation was observed (Fig. 7B).

\section{Discussion}

The present data indicate that exposure of A549 or WI-38 cells to $\mathrm{H}_{2} \mathrm{O}_{2}$ led to rapid induction of ATM activation and $\mathrm{H} 2 \mathrm{AX}$ phosphorylation. The maximal response was observed for Sphase cells (Fig. 1). This observation is compatible with the known mechanism of induction of DNA damage by oxidants that initially leads to formation of DNA single strand lesions, predominantly consisting of 8-oxo-dG, followed by conversion of some of these lesions into DSBs during DNA replication (1-6,50). Because DSBs are the most potent inducers of ATM activation and H2AX phosphorylation (35-40) it would be expected that cells in S-phase responded maximally to short pulse of $\mathrm{H}_{2} \mathrm{O}_{2}$ (Fig. 1).

A good correlation was seen between the rise in expression of both $\gamma \mathrm{H} 2 \mathrm{AX}$ and ATM-S1981 ${ }^{\mathrm{P}}$ induced by $\mathrm{H}_{2} \mathrm{O}_{2}$ which suggests that $\mathrm{H} 2 \mathrm{AX}$ phosphorylation was mediated by ATM. The data also imply that H2AX phosphorylation was not caused by replication stress because in the latter case phosphorylation is mediated by ATR and/or DNA PKes and not by ATM (51). Activation of ATM and phosphorylation of H2AX when occurring concurrently are considered to be a more reliable marker of DNA damage that involves formation of DSBs than phosphorylation of H2AX alone $(52,53)$. Consistent with the induction of DSBs by $\mathrm{H}_{2} \mathrm{O}_{2}$ was also observation of the presence of $\gamma \mathrm{H} 2 \mathrm{AX}$ in form of distinct foci (Fig. 2) instead of its dispersed localization. The number of individual $\gamma \mathrm{H} 2 \mathrm{AX}$ foci per nucleus is being considered to report the number of DSBs (35-38). All the above evidence points out, therefore, that in the cells treated with $\mathrm{H}_{2} \mathrm{O}_{2}$ the induction of $\gamma \mathrm{H} 2 \mathrm{AX}$ reports oxidative DNA damage, some of each leading to formation of DSBs.

Oxidative DNA damage induced by $\mathrm{H}_{2} \mathrm{O}_{2}$ as reflected by induction of $\gamma \mathrm{H} 2 \mathrm{AX}$ was distinctly reduced in cells that were exposed to $\mathrm{H}_{2} \mathrm{O}_{2}$ in the presence of $\mathrm{HA}$. The most pronounced reduction was seen in the presence of high MW $\mathrm{HA}$; in fact, exposure of cells to $\mathrm{H}_{2} \mathrm{O}_{2}$ under these conditions essentially totally prevented the induction of $\gamma \mathrm{H} 2 \mathrm{AX}$ as the level of expression of $\gamma \mathrm{H} 2 \mathrm{AX}$ in these cells was similar to that on the $\mathrm{H}_{2} \mathrm{O}_{2}$-untreated cells. The protective effect was still apparent but was of lesser degree when HA of medium and low MW were used. Similar degree of protection, also related to MW of HA, was observed in WI-38 cells treated with $\mathrm{H}_{2} \mathrm{O}_{2}$ (data not shown).

The data (Figs. 3 and 4) report effect of HA on $\gamma \mathrm{H} 2 \mathrm{AX}$ induction by $\mathrm{H}_{2} \mathrm{O}_{2}$ under conditions when the cells were grown in the presence of HA for $24 \mathrm{~h}$ and were treated with $\mathrm{H}_{2} \mathrm{O}_{2}$ during their final hour of growth. These conditions mimic situation in vivo when cells are growing within intercellular matrix containing HA and are exposed to an exogenous oxidizing agent. In parallel experiments we have also tested the effect of HA added concurrently with $\mathrm{H}_{2} \mathrm{O}_{2}$ for $1 \mathrm{~h}$ on the cells that were prior growing either in absence or presence of $\mathrm{HA}$. In either case a marked protective effect, in terms of reduction of $\gamma \mathrm{H} 2 \mathrm{AX}$ induced by $\mathrm{H}_{2} \mathrm{O}_{2}$, of all HA preparations, but the most pronounced of the high MW, was observed (data not shown).

It has been reported by Campo et al (54), that HA and chondroitin-4-sulphate could reduce DNA fragmentation caused by iron plus ascorbate-induced oxidative stress in human fibroblasts. Their observations, however, were based on measurement of DNA damage in bulk, upon its extraction from large populations of cells. Unlike in the present study, therefore, the authors were unable to relate DNA damage to individual cells and to the cell cycle phase. Furthermore, 
the oxidative stress lasted for $24 \mathrm{~h}$. It is possible that in the course of the stress lasting for so long some cells were undergoing apoptosis. Because during apoptosis DNA is extensively fragmented (55) the DNA fragmentation observed by these authors could be caused not only directly by the oxidants but also could be the result of apoptotic cell death. Nevertheless, their studies provide evidence for the protective effect of HA on cells stressed by oxidants.

It should be noted that HA is promoting wound healing $(56,57)$ and modulating inflammatory processes $(24,25,58-60)$. Because reactive oxidants play key role in inflammation, particularly during oxidative burst of phagocytes/macrophages $(8,61)$, it is likely that the palliative effect of HA in inflammation is mediated to a large extent by its ability to protect cells from reactive oxidants.

As mentioned, the constitutive phosphorylation of histone $\mathrm{H} 2 \mathrm{AX}$ observed in untreated cells reflects to a large extent the ongoing DNA damage induced by endogenous oxidants produced primarily in mitochondria during aerobic metabolism (41-44,46). We observed that HA was able to reduce the level of $\gamma \mathrm{H} 2 \mathrm{AX}$ expression in the untreated WI-38 but not in A549 cells (Figs. 5 and 6). In contrast to the protection from the exogenous $\mathrm{H}_{2} \mathrm{O}_{2}$, that was distinctly lower when the HA of low MW was used, compared to high MW HA (Figs. 3 and 4), no such pattern was apparent in the case of constitutive DNA damage in WI-38 cells. In fact, HA of low MW appeared to have more pronounced effect compared to medium (Fig. 5) or high (not shown) HA. The protective effect of HA from the endogenous oxidants in WI-38 cells would suggest that this biopolymer was more effectively internalized. The hyaluronate transmembrane receptor CD44 is present on plasma membrane of fibroblasts, including WI-38 cells (62), and it has been shown that this receptor mediates internalization of HA via endocytotic pathway (63-65). It is likely, therefore, that in the present study HA was internalized by WI-38 cells by this mechanism and it exerted its protective effects after the internalization. If this is indeed a mechanism of the observed protection, it appears then that the internalization of HA of low MW was more effective than that of the medium MW.

It is unclear why we observed the protective effect of HA on constitutive DNA damage in WI-38 fibroblasts but not of adenocarcinoma A549 cells. One of the mechanisms could be that HA the internalization in the latter cells was less effective. However, most normal epithelial cells express CD44 (66) and its presence on A549 cells have also been reported (67). It was shown, however, that chemical modification such as palmitoylation of CD44 is needed to associate this receptor with lipid rafts and effectively internalize HA via endocytosis (65). It is possible therefore, that A549 cells lack this mechanism and therefore were unable to internalize HA.

Two possible mechanisms may account for the observed protective effect of HA against oxidative DNA damage. One mechanism may be associated with the ability of the polyanion $\mathrm{HA}$ to chelate ions such ad $\mathrm{Fe}^{++}$and $\mathrm{Cu}^{++}(68,69)$. These ions are critical in Fenton's reaction $(70,71)$ in which the superoxide and hydrogen peroxide, which themselves are not strongly reactive towards DNA, are converted into the highly reactive hydroxyl radical $\left(\mathrm{OH}^{*}\right)$ known to produce a multiplicity of chemical modifications in DNA. Another mechanism may involve direct scavenging by HA of reactive oxidant molecules, particularly the reactive products of Fenton's reaction such as $\mathrm{OH}^{*}$. The observed in vitro fragmentation of $\mathrm{HA}$ by $\mathrm{H}_{2} \mathrm{O}_{2}$ in the presence of $\mathrm{FeSO}_{4}$ in tissue culture media (Fig. 7B) is consistent with the second mechanism. Namely, the radical scavenging activity by HA results in its breakdown and depletes the pool of oxidants that otherwise will damage DNA. This supports the proposition that one of the HA biological functions is to provide protection against cellular damage caused by radicals produced by oxidative reductive systems or ionizing radiation (72). Consistent with this interpretation are findings of Hutadilok et al (33), who observed that exposure of synovial fibroblasts to low concentrations of $\mathrm{H}_{2} \mathrm{O}_{2}$ stimulated synthesis of $\mathrm{HA}$. Apparently the initiation of $\mathrm{HA}$ degradation by $\mathrm{H}_{2} \mathrm{O}_{2}$ triggered compensatory production of high MW HA thereby enhancing the antioxidant defense.

The presence of the hyaluronate-receptor CD44 on the surface of stem cells is a well recognized fact (73) although its function in these cells is not entirely understood (74). However, it is known that stem cells are equipped in variety of defense mechanisms, particularly protecting their DNA from oxidative damage (75). In light of the evidence presented by us that hyaluronate prevents DNA damage by endogenous oxidants in WI-38 cells, the cells that express CD44, it is tempting to speculate that one of the functions of CD44 in stem cells may be to facilitate endocytosis of hyaluronate which then may act as protector of their DNA from oxidants. Interestingly, the lipid raft modification (clustering) on stem cells seems to be the key event triggering their entrance to the cell cycle (76). The internalization of CD44-bound hyaluronan requires CD44 association (upon its palmitoylation) with lipid rafts (65). Modifications of lipid rafts on stem cells, thereby, provide signals controlling both the cell cycle status (quiescence vs. proliferation) and internalization of HA. The stem cell thus may have several diverse mechanisms to protect integrity of its DNA, such as low metabolic activity that ensures minimal level of oxidative DNA damage, highly effective efflux pump that rapidly removes genotoxic agents from the cell (77), and possibly internalization of HA which protects DNA from oxidants. These mechanisms may be coordinated with each other and with the cell cycle status.

\section{Acknowledgements}

This study was supported by NCI RO1 CA 28704 and Biomatrix, Inc.

\section{References}

1. Barzilai A and Yamamoto K: DNA damage responses to oxidative stress. DNA Repair 3: 1109-1115, 2004.

2. Nohl H: Generation of superoxide radicals as byproducts of cellular respiration. Ann Biol Clin 52: 199-204, 1994.

3. Moller $\mathrm{P}$ and Loft $\mathrm{S}$ : Interventions with antioxidants and nutrients in relation to oxidative DNA damage and repair. Mutat Res 551: 79-89, 2004

4. Beckman KB and Ames BN: Oxidative decay of DNA. J Biol Chem 272: 13300-13305, 1997.

5. Dianov GL and Parsons JL: Co-ordination of DNA single strand break repair. DNA Repair 6: 454-460, 2007.

6. Vilenchik MM and Knudson AG: Endogenous DNA doublestrand breaks: production, fidelity of repair, and induction of cancer. Proc Natl Acad Sci USA 100: 12871-12876, 2003. 
7. Taioli E, Sram RJ, Garte BM, Kalina I, Popov TA and Farmer PB: Effects of polycyclic aromatic hydrocarbons (PAHs) in environmental pollution on exogenous and oxidative DNA damage (EXPAH project): description of the population under study. Mutat Res 620: 1-6, 2007.

8. Tanaka T, Halicka HD, Traganos F and Darzynkiewicz Z: Phosphorylation of histone H2AX on Ser 139 and activation of ATM during oxidative burst in phorbol ester-treated human leukocytes. Cell Cycle 5: 2671-2675, 2006.

9. Shacter E, Beecham EJ, Covey JM, Kohn KW and Potter M: Activated neutrophils induce prolonged DNA damage in neighboring cells. Carcinogenesis 9: 2297-2304, 1988.

10. Chong YC, Heppner GH, Paul LA and Fulton AM: Macrophagemediated induction of DNA strand breaks in target tumor cells. Cancer Res 49: 6652-6657, 1989.

11. Demirbag R, Yilmaz R, Kocyigit A and Guzel S: Effect of coronary angiography on oxidative DNA damage observed in circulating lymphocytes. Angiology 58: 141-147, 2007.

12. Floyd RA, West M and Henssley K: Oxidative biochemical markers; clues to understanding aging in long-lived species. Exp Gerontol 36: 619-640, 2001

13. Marnett LJ, Riggins JN and West JD: Endogenous generation of reactive oxidants and electrophiles and their reactions with DNA and protein. J Clin Invest 111: 583-593, 2003.

14. Altman SA, Zastawny TH, Randers-Eichorn L, Caciuttolo MA, Akman SA, Disdaroglu M and Rao G: Formation of DNAprotein cross-links in cultured mammalian cells upon treatment with iron ions. Free Radic Biol Med 19: 897-902, 1995.

15. Cadet J, Delatour T, Douki T, Gasparutto D, Pouget JP, Ravanat JL and Sauvaigo S: Hydroxyl radicals and DNA base damage. Mutat Res 424: 9-21, 1999.

16. Marnett LJ: Oxy radicals, lipid peroxidation and DNA damage. Toxicology 181-182: 219-222, 2002.

17. Pastwa E and Blasiak J: Non-homologous DNA end joining. Acta Biochim Pol 50: 891-908, 2003

18. Jeggo PA and Lobrich M: Artemis links ATM to double strand end rejoining. Cell Cycle 4: 359-362, 2005.

19. Gorbunova V and Seluanov A: Making ends meet in old age: DSB repair and aging. Mech Ageing Dev 126: 621-628, 2005.

20. Karanjawala ZE and Lieber MR: DNA damage and aging. Mech Ageing Dev 125: 405-416, 2004.

21. Parrinello S, Samper E, Krtolica A, Goldstein J, Melov S and Campisi J: Oxygen sensitivity severely limits the replicative lifespan of murine fibroblasts. Nat Cell Biol 5: 741-747, 2003.

22. Schriner SE, Linford NJ, Martin GM, Treuting P, Ogburn CE, Emond M, Coskun PE, Ladiges W, Wolf N, van Remmen H, Wallace DC and Rabinovitch PS: Extension of murine life span by over expression of catalase targeted to mitochondria. Science 308: 1875-1878, 2005.

23. Arai H, Kashiwagi S, Nagasaka Y, Uchida K, Hoshii Y and Nakamura K: Oxidative modification of apolipoprotein $\mathrm{E}$ in human very-low density lipoprotein and its inhibition by glycosaminoglycans. Arch Biochem Biophys 367: 1-8, 1999.

24. Campo GM, Avenoso A, Campo S, Ferlazzo AM, Altavilla A and Calatroni A: Efficacy of treatment with glycosaminoglycans on experimental collagen-induced arthritis in rats. Arthritis Res Ther 5: R122-R131, 2003.

25. Campo GM, Avenoso A, Campo S, Ferlazzo AM, Altavilla D, Micali C and Calatroni A: Aromatic trap analysis of free radicals production in experimental collagen-induced arthritis in the rat: protective effect of glycosaminoglycans treatment. Free Radic Res 37: 257-268, 2003.

26. Albertini R, Passi A, Abuja PM and De Luca G: The effect of glycosaminoglycans and proteoglycans on lipid peroxidation. Int J Mol Med 6: 126-136, 2000.

27. Balazs EA: Viscosupplementation for treatment of osteoarthritis: from initial discovery to current status and results. Surg Technol Int 12: 278-289, 2004.

28. Robertson WV, Ropes MW and Bauer W: The degradation of mucins and polysaccharides by ascorbic acid and hydrogen peroxide. Biochem J 35: 903-908. 1941.

29. Skanse B and Sundblad L: Oxidative breakdown of hyaluronic and chondroitin sulphuric acid. Acta Physiol Scand 6: 37-51, 1943.

30. Matsumura G and Pigman W: Catalytic role of copper and iron ions in the depolymerization of hyaluronic acid by ascorbic acid. Arch Biochem Biophys 110: 526-533, 1965.

31. Greenwald RA and Moy WW: Effect of oxygen-derived free radicals on hyaluronic acid. Arthritis Rheum 23: 455-463, 1980.
32. Wong SF, Halliwell B, Richmond R and Skowroneck WR: The role of superoxide and hydroxyl radicals in the degradation of hyaluronic acid induced by metal ions and by ascorbic acid. $\mathbf{J}$ Inorg Biochem 14: 127-134, 1981.

33. Hutadilok N, Smith MM and Ghosh P: Effect of hydrogen peroxide on the metabolism of human rheumatoid and osteoarthritic synovial fibroblasts in vitro. Ann Rheum Dis 50: 219-226, 1991.

34. Soltes L, Kogan G, Stankovska M, Mendichi R, Rychly R, Schiller $J$ and Gemeiner P: Degradation of high-molar-mass hyaluronan and characterization of fragments. Biomacromolecules 8: 2697-2705, 2007.

35. Rogakou EP, Pilch DR, Orr AH, Ivanova VS and Bonner WM: DNA double-stranded breaks induce histone H2AX phosphorylation on serine 139. J Biol Chem 273: 5858-5868, 1998.

36. Sedelnikova OA, Rogakou EP, Panuytin IG and Bonner W: Quantitive detection of 125IUdr-induced DNA double-strand breaks with $\gamma-\mathrm{H} 2 \mathrm{AX}$ antibody Radiat Res 158: 486-492, 2002.

37. Burma S, Chen BP, Murphy M, Kurimasa A and Chen DJ: ATM phosphorylates histone $\mathrm{H} 2 \mathrm{AX}$ in response to DNA double-strand breaks. J Biol Chem 276: 42462-42467, 2001.

38. Downs JA and Cote J: Dynamics of chromatin during the repair of DNA double-strand breaks. Cell Cycle 4: 1373-1376, 2005.

39. Bassing $\mathrm{CH}$ and Alt $\mathrm{FW}$ : $\mathrm{H} 2 \mathrm{AX}$ may function as an anchor to hold broken chromosomal DNA ends in close proximity. Cell Cycle 3: 149-153, 2004

40. Downey $\mathrm{M}$ and Durocher D: $\gamma \mathrm{H} 2 \mathrm{AX}$ as a checkpoint maintenance signal. Cell Cycle 5: 1376-1381, 2006.

41. Tanaka T, Halicka HD, Huang $X$, Traganos $F$ and Darzynkiewicz Z: Constitutive histone H2AX phosphorylation and ATM activation, the reporters of DNA damage by endogenous oxidants. Cell Cycle 5: 1940-1945, 2006.

42. Tanaka T, Kurose A, Halicka HD, Traganos F and Darzynkiewicz Z: 2-Deoxy-D-glucose reduces the level of constitutive activation of ATM and phosphorylation of histone H2AX. Cell Cycle 5: 878-882, 2006.

43. Tanaka T, Kajstura M, Halicka HD, Traganos F and Darzynkiewicz Z: Constitutive histone H2AX phosphorylation and ATM activation are strongly amplified during mitogenic stimulation of lymphocytes. Cell Prolif 40: 1-13, 2007.

44. Zhao H, Tanaka T, Halicka HD, Traganos F, Zarebski M, Dobrucki J and Darzynkiewicz Z: Cytometric assessment of DNA damage by exogenous and endogenous oxidants reports the aging-related processes. Cytometry A 71A: 905-914, 2007.

45. Ismail IH, Wadhra TI and Hammarsten O: An optimalized method for detecting gamma-H2AX in blood cells reveals a significanty individual variation in the gamma- $\mathrm{H} 2 \mathrm{AX}$ response among humans. Nucleic Acids Res 35: e1-10, 2007.

46. Huang X, Tanaka T, Kurose A, Traganos F and Darzynkiewicz Z: Constitutive histone H2AX phosphorylation on Ser-139 in cells untreated by genotoxic agents is cell-cycle phase specific and attenuated by scavenging reactive oxygen species. Int J Oncol 29: 495-501, 2006.

47. Darzynkiewicz Z, Bedner E, Gorczyca W and Melamed MR: Laser scanning cytometry. A new instrumentation with many applications. Exp Cell Res 249: 1-12, 1999.

48. Lee HG and Cowman MK: An agarose gel electrophoretic method for analysis of hyaluronan molecular weight distribution. Anal Biochem 219: 278-287, 1994.

49. Li M, Rosenfeld L, Vilar RE and Cowman MK: Degradation of hyaluronan by peroxynitrite. Arch Biochem Biophys 341: 245-250, 1997.

50. Chen JH, Ozanne SE and Hales $\mathrm{CN}$ : Heterogeneity in premature senescence by oxidative stress correlates with differential DNA damage during the cell cycle. DNA Repair 28: 1140-1158, 2005.

51. Ward IM and Chen J: Histone H2AX is phosphorylated in an ATR-dependent manner in response to replicational stress. J Biol Chem 276: 47759-47762, 2001

52. Bakkenist CJ and Kastan MB: DNA damage activates ATM through intermolecular autophosphorylation and dimer dissociation. Nature 421: 499-506, 2003.

53. Paull TT and Lee JH: The Mre11/Rad50/Nbs1 complex and its role as a DNA-double strand break sensor for ATM. Cell Cycle 4: 737-740, 2005

54. Campo GM, Avenoso A, Campo S, D'Ascola A, Ferlazzo AM and Calatroni A: Reduction of DNA fragmentation and hydroxyl radical production by hyaluronic acid and chondroitin-4sulphate in iron plus ascorbate-induced oxidative stress in fibroblast cultures. Free Radic Res 38: 601-611, 2004. 
55. Gorczyca W, Bruno S, Darzynkiewicz RJ, Gong JP and Darzynkiewicz Z: DNA strand breaks occurring during apoptosis: their early in situ detection by the terminal deoxynucleotidyl transferase and nick translation assays and prevention by serine protease inhibitors. Int J Oncol 1: 639-648, 1992.

56. Chen WY and Abatangelo G: Functions of hyaluronan in wound repair. Wound Repair Regen 7: 79-89, 1999.

57. Haider AS, Grabarek J, Eng B, Pedraza P, Ferreri NR, Balazs EA and Darzynkiewicz Z: In vitro wound healing analyzed by laser scanning cytometry. Accelerated healing of epithelial cell monolayers in the presence of hyaluronate. Cytometry A 53A: 1-8, 2003.

58. Balazs EA and Darzynkiewicz Z: The effect of hyaluronic acid on fibroblasts, mononuclear phagocytes and lymphocytes. In Biology of the Fibroblast, Papers of the Symposium held in Turku, Finland, 1972. Kulonen E and Pikkarainen J (eds.) Academic Press, London, pp237-252, 1973.

59. Suzuki Y and Yamaguchi T: Effects of hyaluronic acid on macrophage phagocytosis and active oxygen release. Agents Action 38: 332-337, 1993

60. Fukuda K, Takayama M, Ueno M, Oh M, Asada S, Kumano F and Tanaka S: Hyaluronic acid inhibits interleukin-1-induced superoxide anion in bovine chondrocytes. Inflam Res 46: 114-117, 1997.

61. Quinn MT and Gauss KA: Structure and regulation of the neutrophil respiratory burst: comparison with nonphagocytic oxidases. J Leukoc Biol 76: 760-781, 2004.

62. Neame SJ and Isacke CM: The cytoplasmic tail of CD44 is required for basolateral localization in epithelial MDCK cells but does not mediate association with the detergent-insoluble cytoskeleton of fibroblasts. J Cell Biol 121: 1299-1310, 1993.

63. Basner-Tschakarjan E, Mirmohammadsadegh A, Baer A and Hengge UR: Uptake and trafficking of DNA in keratinocytes: evidence for DNA-binding proteins. Gene Ther 11: 765-774, 2004.

64. Embry JJ and Knudson W: G1 domain of aggrecan cointernalizes with hyaluronan via a CD44-mediated mechanism in bovine articular chondrocytes. Arthritis Rheum 48: 3431-3441, 2003.

65. Thankamony SP and Knudson W: Acetylation of CD44 and its association with lipid rafts are required for receptor and hyaluronan endocytosis. J Biol Chem 281: 34601-34609, 2006.
66. Alho AM and Underhill CB: The hyaluronate receptor is preferentially expressed on proliferating epithelial cells. J. Cell Biol 108: 1557-1565, 1989

67. Backhus LM, Sievers E, Lin G, Castanos R, Bart RD, Starnes VA and Bremner RM: Perioperative cyclooxygenase 2 inhibition to reduce tumor cell adhesion and metastatic potential of circulating tumor cells in non-small cell lung cancer. J Thorac Cardiovasc Surg 132: 297-303, 2006.

68. Balogh GT, Illes J, Szekely Z, Forrai E and Gere A: Effect of different metal ions on the oxidative damage and antioxidant capacity of hyaluronic acid. Arch Biochem Biophys 410: 76-82, 2003

69. Nagy L, Yamashita S, Yamaguchi S, Sipos P, Wakita H and Nomura M: The local structures of $\mathrm{Cu}(\mathrm{II})$ and $\mathrm{Zn}(\mathrm{II})$ complexes of hyaluronate. J Inorg Biochem 72: 49-55, 1998.

70. Koppenol WH: The Haber-Weiss cycle - 70 years later. Redox Rep 7: 55-57, 2002.

71. Valko M, Morris H and Cronin MT: Metals, toxicity and oxidative stress. Curr Med Chem 12: 12: 1161-1208, 2005.

72. Balazs E, Davies J, Phillips G and Young M: Transient intermediates in the radiolysis of hyaluronic acid. Radiat Res 31 243-255, 1967

73. Sales KM, Winslet MC and Seifalian A: Stem cells and cancer: an overview. Stem Cell Rev 3: 249-255, 2007.

74. Paulsom R: CH44 and hyaluronan help mesenchymal stem cells move to a neighborhood in need of regeneration. Kidney Int 72 389-390, 2007

75. Stambrook PJ: An ageing question: do embryonic stem cells protect their genomes? Mech Ageing Dev 128: 31-35, 2007.

76. Yamazaki S, Iwama A, Morita Y, Eto K, Ema H and Nakauchi $H$ : Cytokine signaling, lipid raft clustering, and HSC hibernation. Ann NY Acad Sci 1106: 54-63, 2007.

77. Reeijmakers MHGP: ATP-binding-cassette transporters in hematopoietic stem cells and their utility as therapeutic targets in acute and chronic myeloid leukemia. Leukemia 21: 2094-2102, 2007. 